\title{
Article
}

\section{Recovery of Spent Sulphuric Acid by Diffusion Dialysis Using a Spiral Wound Module}

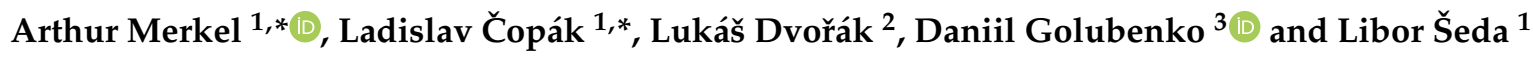 \\ 1 MemBrain s. r. o. (Membrane Innovation Centre), Pod Vinicí 87, 47127 Stráž pod Ralskem, Czech Republic; \\ libor.seda@membrain.cz \\ 2 Institute for Nanomaterials, Advanced Technologies and Innovation, Technical University of Liberec, \\ Studentská 2, 46117 Liberec, Czech Republic; lukas.dvorak@tul.cz \\ 3 Kurnakov Institute of General and Inorganic Chemistry of the Russian Academy of Sciences, \\ 31 Leninsky Avenue, 119991 Moscow, Russia; golubenkodaniel@yandex.ru \\ * Correspondence: arthur.merkels@gmail.com (A.M.); ladislav.copak@membrain.cz (L.Č.); \\ Tel.: +420-777-539-924 (A.M.); +420-720-051-738 (L.Č.)
}

Citation: Merkel, A.; Čopák, L.; Dvořák, L.; Golubenko, D.; Šeda, L. Recovery of Spent Sulphuric Acid by Diffusion Dialysis Using a Spiral Wound Module. Int. J. Mol. Sci. 2021, 22, 11819. https://doi.org/10.3390/ ijms222111819

Academic Editor: Victor

V. Nikonenko

Received: 4 October 2021

Accepted: 28 October 2021

Published: 30 October 2021

Publisher's Note: MDPI stays neutral with regard to jurisdictional claims in published maps and institutional affiliations.

Copyright: (c) 2021 by the authors. Licensee MDPI, Basel, Switzerland. This article is an open access article distributed under the terms and conditions of the Creative Commons Attribution (CC BY) license (https:// creativecommons.org/licenses/by/ $4.0 /)$.

\begin{abstract}
In this study, we assess the effects of volumetric flow and feed temperature on the performance of a spiral-wound module for the recovery of free acid using diffusion dialysis. Performance was evaluated using a set of equations based on mass balance under steady-state conditions that describe the free acid yield, rejection factors of metal ions and stream purity, along with chemical analysis of the outlet streams. The results indicated that an increase in the volumetric flow rate of water increased free acid yield from $88 \%$ to $93 \%$, but decreased $\mathrm{Cu}^{2+}$ and $\mathrm{Fe}^{2+}$ ion rejection from $95 \%$ to $90 \%$ and $91 \%$ to $86 \%$, respectively. Increasing feed temperature up to $40{ }^{\circ} \mathrm{C}$ resulted in an increase in acid flux of $9 \%$, and a reduction in $\mathrm{Cu}^{2+}$ and $\mathrm{Fe}^{2+}$ ion rejection by $2-3 \%$. Following diffusion dialysis, the only evidence of membrane degradation was a slight drop in permselectivity and an increase in diffusion acid and salt permeability. Results obtained from the laboratory tests used in a basic economic study showed that the payback time of the membrane-based regeneration unit is approximately one year.
\end{abstract}

Keywords: anion-exchange homogeneous membrane; membrane degradation; mass balance; case study; payback time

\section{Introduction}

Industrial processes often generate wastewaters characterized by high acidity or high alkalinity with $\mathrm{pH}$ lower than 1 and above 14 respectively in some cases and/or a high metal content [1,2]. Membrane technologies facilitate the recovery of valuable dissolved components such as metals and allow the reuse of acids or alkalis. Among the various membrane technologies presently available, diffusion dialysis (DD), nanofiltration (NF), electrodialysis (ED), membrane distillation (MD) and forward osmosis (FO) are the most promising as regards the circular economy paradigm $[3,4]$. It is widely believed that DD represents the optimal process for recovery of acids at high concentrations (i.e., $>0.5 \mathrm{M}$ ) [3]. Compared to other technologies, DD has a number of advantages [5,6], including low energy consumption (due to spontaneous processes driven by activity gradients), low installation costs, simple operation and maintenance, and high product quality (due to the high selectivity of anion-exchange membranes (AEMs) for acids). In addition, the process is considered environmentally friendly due to the lack of post-processing and chemical agents used [3,4,7].

DD is a membrane separation process driven by a concentration gradient and, in environmental engineering, it is mainly used for the recovery of spent acids or alkalis $[5,8]$. The basic principle of separation utilises the high membrane permeability of acids and alkalis relative to metal salts, in association with proton-transport via the hydrogen bond 
network of water molecules, a process known as the 'Grotthuss mechanism' [9-11]. This latter process explains why DD is most often used specifically to recover acids [3]. AEMs are the most frequently used materials for processing of acids via DD. Owing to the positively charged polymer matrix surrounding the pores, diffusion of cations, such as $\mathrm{Fe}^{2+}, \mathrm{Fe}^{3+}, \mathrm{Cu}^{2+}$ or $\mathrm{Pb}^{2+}$ slows down in the AEM-matrix, making it possible to achieve higher selectivity coefficients [6]. In recent years, development of DD has focused on the synthesis of new membranes and modifications to known materials [12-15], optimization of module structure $[16,17]$, expanding known applications and researching potential new applications [17-22].

While laboratory-scale acid recovery experiments using DD are mainly conducted in batch configurations, plant-scale operations benefit from the use of a continuous dialyser, which provides a number of advantages, including higher productivity, lower costs, convenient assemblage and transportation and a continuous process more appropriate for practical production-level use $[6,18]$. As such, the next step towards advanced DD is usually seen as optimization of the module configuration. At present, 'plate-and-frame' is the most commonly used membrane module type; however, the space-saving characteristics and modular nature of spiral-wound DD membrane modules has recently attracted much attention $[6,17,23]$. Zhang et al. [23], for example, while studying the process of hydrochloric acid separation from aluminium salts using a DD spiral-wound membrane module, showed that acid yield, recovered acid concentration and metal salts rejection were all affected by diffusate and dialysate flow rates. According to these authors, the optimized ratio of feed over water flow rate is around 1. A relative increase in the feed (dialysate) flow led to a decrease in acid yield due to the reduction in solution contact time in the module, while the concentration of recovered acid and leaked aluminium salts increased.

Membrane stability is a key factor for their use in DD, which characterizes the steadiness of the membrane's physicochemical properties such as permeability and separation factor under operation conditions [6]. In characterizing such membranes, researchers tend to concentrate on the alkaline-stability of AEMs [24], primarily due to their frequent use in alkaline fuel cells. In comparison, there is relatively little data available on the acid-stability of AEMs. Commercial AEMs for DD tend to be more stable than nanofiltration membranes in acid solutions when used for acid recovery based on polyamides [3]. Indeed, it has been reported that commercial and tailor-made AEMs for DD based on bromomethylated poly(phenylene oxide) (BPPO) degrade noticeably in acid solutions within $72 \mathrm{~h}[25,26]$, with both loss of mass and reduced ion-exchange capacity reported. Other studies, however, have reported high stability of BPPO-based membranes in acid solutions [27].

In the present study, we assess the capacity of a spiral-wound module designed for continuous recovery of free acid using DD to separate sulphuric acid and $\mathrm{Cu}^{2+}$ and $\mathrm{Fe}^{2+}$ salts. During this experimental campaign, we also investigate impact of volumetric flow and feed temperature on module performance and assess membrane degradation through characterization of ion-exchange capacity and mechanical and transport properties before and after DD operation.

\section{Results}

\subsection{Effect of Volumetric-Flow Ratio}

Electrical conductivity of the outlet streams increases over time for Test 1.1. This behaviour is caused by the fact that diluted acidic solutions have higher conductivity than demineralized water which was present in the module before its run-up. Steady state of the system is visible from the 90th minute of the process on (Figure 1a). In case of Test 2.1, when module was filled with liquid from the previous test, electrical conductivity of both outlet streams decreases over time. From this observation results that acid is recovered with higher efficiency. The electrical conductivity of the regenerated acid is on average 6 to 8 times higher than the electrical conductivity of the processed salty acid stream leaving the module. The stationary electrical conductivity of the diffusate is higher in the case of Test 1.1 (Figure 1a, $191 \mathrm{mS} \cdot \mathrm{cm}^{-1}$ ) than in the case of Test 2.1 (Figure 2a, $160 \mathrm{mS} \cdot \mathrm{cm}^{-1}$ ). 
This comparison implies that a volumetric-flow ratio has an impact on the concentration of free acid in the diffusate. A higher flux of acid in the case of Test 2.1 is caused by a higher logarithmic mean of concentration difference (a driving force for mass transfer). For this reason, the mass flow of free acid per exchange-area unit is higher and results in a bigger yield (Table 1). Last two points of dialysate flow rate for Test 1.1 exhibit a relatively big deviation from previously measured values (Figure 1b). Small perturbation could be caused by inaccuracy of the flow valves used for regulation of the inlet feed flowrate. No difficulties were observed with maintaining the set value of flowrate of the inlet streams for Test 2.1 (Figure 2b).

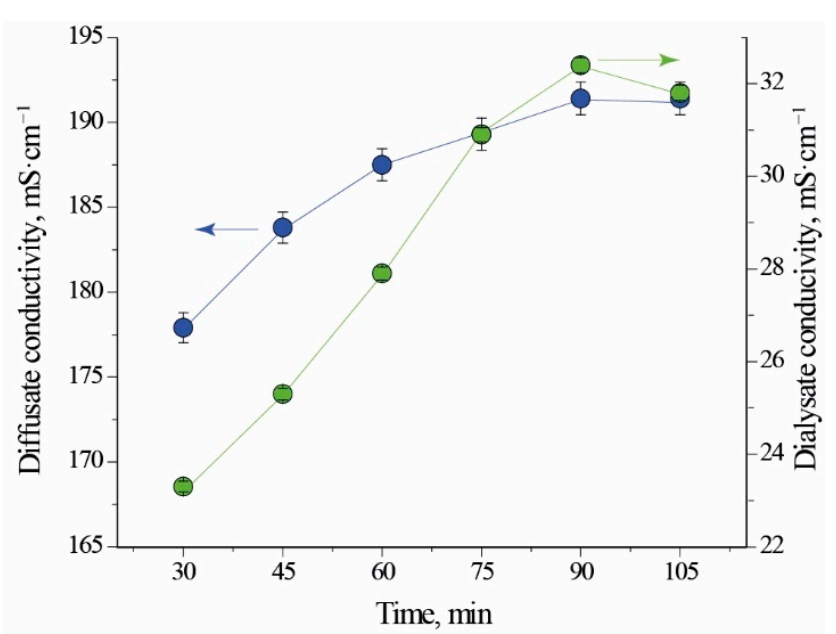

(a)

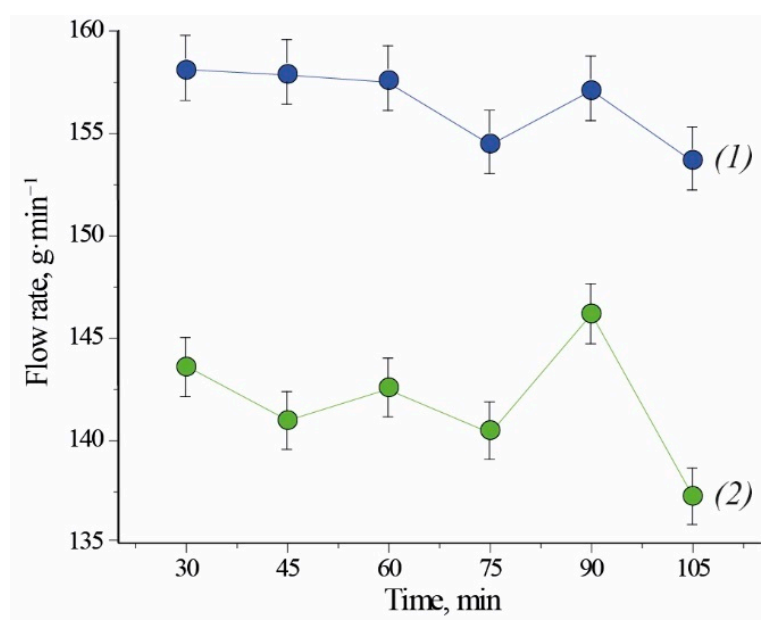

(b)

Figure 1. Conductivity (a) and flow rate (b) as a function of time for Test 1.1. (1) diffusate; (2) dialysate. Initial fill: water. Note that the lines connecting experimental points are not true trendlines.

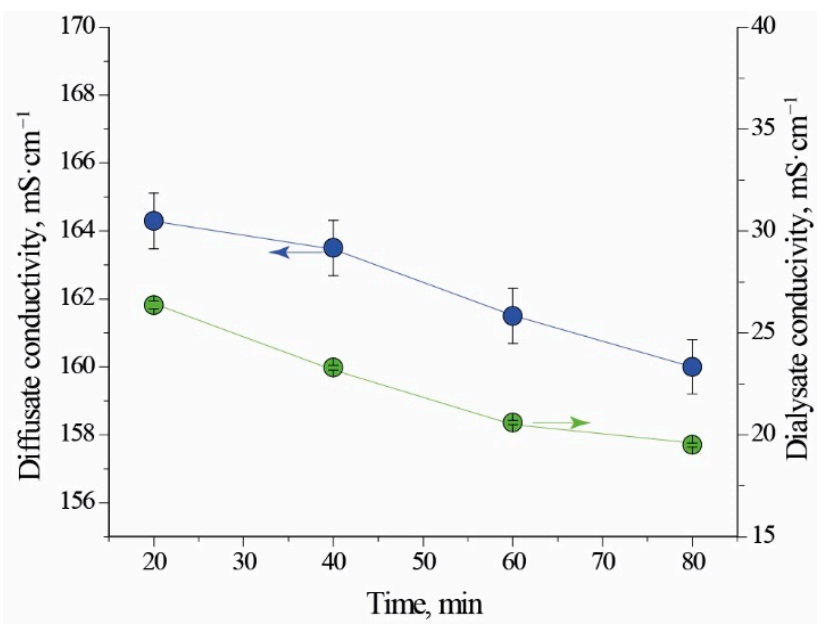

(a)

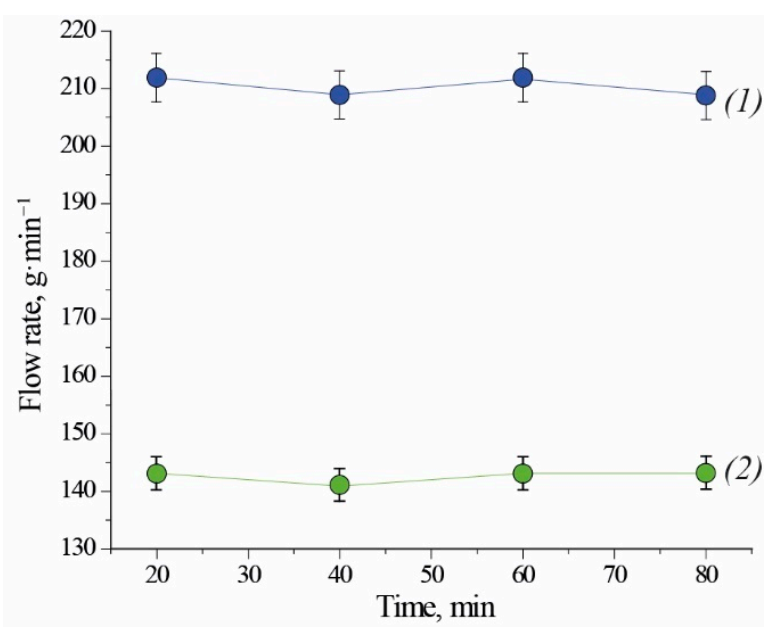

(b)

Figure 2. Conductivity (a) and flow rate (b) as a function of time for Test 2.1. (1) diffusate; (2) dialysate. Initial fill: DD profile from the previous testing. Note that the lines connecting experimental points are not true trendlines.

Evidence that the mass transfer occurs in the dialyser can be concluded from the change in the measured flow rates of the inlet stripping medium and the diffusate (Table 2). Preferential transfer of acid is visible from the composition of the streams. In diffusate is present mainly sulphuric acid beside solvent and small amount of iron and copper sulphates. On the contrary, most salts are in dialysate, whereas sulphuric acid is almost not present. Change in composition is also visible in densities of the solutions. Dialysate leaving the module is less dense than feed because of the missing acid (Table 3). 
Table 1. Summarized values for performance parameters used for Tests 1.1 and 2.1. Symbols: $Y$-yield of acid, $R_{\mathrm{Cu}}{ }^{2+}$-rejection of $\mathrm{Cu}^{2+}, R_{\mathrm{Fe}}{ }^{2+}$-rejection of $\mathrm{Fe}^{2+}, J_{\mathrm{H}_{2} \mathrm{SO}_{4}}$ - flux of acid, $w_{\mathrm{H}_{2} \mathrm{SO}_{4}, \text { FEED (DIF/DIA) }}$-weight fraction of acid in feed (diffusate/dialysate) solution, $P_{\mathrm{FEED} \text { (DIF) }}$ ionic purity of feed (diffusate).

\begin{tabular}{cccc}
\hline Parameter & Unit & Test 1.1 & Test 2.1 \\
\hline$Y$ & $\%$ & $88 \pm 5$ & $93 \pm 6$ \\
$R_{\mathrm{Cu}}{ }^{2+}$ & $\%$ & $95 \pm 5$ & $90 \pm 10$ \\
$R_{\mathrm{Fe}}{ }^{2+}$ & $\%$ & $91 \pm 9$ & $86 \pm 10$ \\
$J_{\mathrm{H}_{2} \mathrm{SO}_{4}}$ & $\mathrm{~g} \cdot \mathrm{m}^{-2} \cdot \mathrm{h}^{-1}$ & $81 \pm 3$ & $87 \pm 3$ \\
$w_{\mathrm{H}_{2} \mathrm{SO}_{4}, F E E D}$ & $\%$ & $5.18 \pm 0.10$ & $4.84 \pm 0.10$ \\
$w_{\mathrm{H}_{2} \mathrm{SO}_{4}, D I F}$ & $\%$ & $4.39 \pm 0.09$ & $3.48 \pm 0.07$ \\
$w_{\mathrm{H}_{2} \mathrm{SO}_{4}, D I A}$ & $\%$ & $0.66 \pm 0.01$ & $0.41 \pm 0.01$ \\
$P_{\mathrm{FEED}}$ & $\%$ & $76.8 \pm 1.3$ & $76.0 \pm 1.3$ \\
$P_{\text {DIF }}$ & $\%$ & $97.5 \pm 0.2$ & $95.6 \pm 0.3$ \\
$P_{\mathrm{DIF}} / P_{\text {DIA }}$ & - & 3.2 & 4.4 \\
\hline
\end{tabular}

Table 2. Flows of inlet and outlet streams (volumetric flows in $\mathrm{L} \cdot \mathrm{h}^{-1}$ and mass flows in $\mathrm{kg} \cdot \mathrm{h}^{-1}$ ).

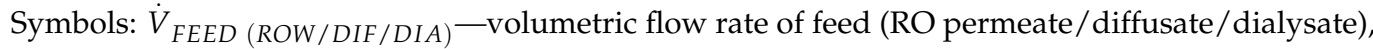
$\dot{m}_{F E E D}(R O W / D I F / D I A)$-mass flow rate of feed (RO permeate/diffusate/dialysate).

\begin{tabular}{ccc}
\hline Parameter & Test 1.1 & Test 2.1 \\
\hline$\dot{V}_{\text {FEED }}$ & $8.55 \pm 0.05$ & $9.42 \pm 0.05$ \\
$\dot{V}_{R O W}$ & $8.64 \pm 0.05$ & $11.45 \pm 0.05$ \\
$\dot{V}_{D I F}$ & $8.98 \pm 0.09$ & $12.28 \pm 0.12$ \\
$\dot{V}_{D I A}$ & $8.21 \pm 0.08$ & $8.58 \pm 0.09$ \\
$\dot{m}_{F E E D}$ & $8.83 \pm 0.05$ & $9.70 \pm 0.05$ \\
$\dot{m}_{R O W}$ & $8.63 \pm 0.05$ & $11.42 \pm 0.05$ \\
$\dot{m}_{D I F}$ & $9.22 \pm 0.18$ & $12.53 \pm 0.25$ \\
$\dot{m}_{D I A}$ & $8.24 \pm 0.16$ & $8.59 \pm 0.17$ \\
\hline
\end{tabular}

Table 3. Analytical measurements for Tests 1.1 and 2.1.

\begin{tabular}{cccccccc}
\hline Composition & Unit & Feed & Diffusate & Dialysate & Feed & Diffusate & Dialysate \\
\hline & & Test 1.1 & & Test 2.1 \\
\hline $\mathrm{H}_{2} \mathrm{SO}_{4}$ & $\mathrm{~g} \cdot \mathrm{L}^{-1}$ & $53.5 \pm 1.1$ & $45.0 \pm 0.9$ & $6.6 \pm 0.1$ & $50.0 \pm 1.0$ & $35.5 \pm 0.7$ & $4.1 \pm 0.1$ \\
$\mathrm{Fe}^{2+}$ & $\mathrm{ppm}$ & $284 \pm 14$ & $21 \pm 1$ & $263 \pm 13$ & $282 \pm 14$ & $30 \pm 2$ & $263 \pm 13$ \\
$\mathrm{Cu}^{2+}$ & $\mathrm{ppm}$ & $50 \pm 3$ & $3.2 \pm 0.2$ & $50 \pm 3$ & $43 \pm 2$ & $3.4 \pm 0.2$ & $42 \pm 2$ \\
Density & $\mathrm{kg} \cdot \mathrm{L}^{-1}$ & $1.033 \pm 0.001$ & $1.026 \pm 0.001$ & $1.004 \pm 0.001$ & $1.030 \pm 0.001$ & $1.020 \pm 0.001$ & $1.001 \pm 0.001$ \\
\hline
\end{tabular}

\subsection{Effect of Feed Temperature}

The temperature of the feed for Test 1.2 under laboratory conditions gradually increased (from $22.1{ }^{\circ} \mathrm{C}$ at the beginning to $24.4{ }^{\circ} \mathrm{C}$ at the end of the test lasting $135 \mathrm{~min}$ ). This is caused by the dissipation of mechanical energy delivered by the pump. Since part of the pumped feed solution is warmer and recycled back to the feed vessel, it mixes with colder liquid which increases the feed temperature. In the remaining tests (Test 2.2 and 3.2), the set value of temperature was maintained without any issues.

Sulphuric-acid yield does not change much and remains constant over studied temperature range, $76 \%$. The value is low, which is caused by the low flow ratio of input streams (Table 4). Furthermore, this is proof that different volumetric flows of input streams can significantly influence system performance. The measured flow rates again prove that mass transfer occurs in the dialyser and is visible in the increase of the mass flow rate between the inlet RO permeate and the diffusate (Table 5). 
Table 4. Summarized values of performance parameters used for Tests 1.2, 2.2, and 3.2. Symbols: $T_{\text {FEED }}$-temperature of feed, $Y$-yield of acid, $R_{\mathrm{Cu}}{ }^{2+}$-rejection of $\mathrm{Cu}^{2+}, R_{\mathrm{Fe}}{ }^{2+}$-rejection of $\mathrm{Fe}^{2+}$, $J_{\mathrm{H}_{2} \mathrm{SO}_{4}}$-flux of acid, $w_{\mathrm{H}_{2} \mathrm{SO}_{4}, \text { FEED (DIF/DIA) }}$-weight fraction of acid in feed (diffusate/dialysate) solution, $P_{\text {FEED (DIF) }}$-ionic purity of feed (diffusate).

\begin{tabular}{ccccc}
\hline Parameter & Unit & Test 1.2 & Test 2.2 & Test 3.2 \\
\hline$T_{\mathrm{FEED}}$ & ${ }^{\circ} \mathrm{C}$ & $20-25$ & 30 & 40 \\
$Y$ & $\%$ & $75 \pm 4$ & $76 \pm 4$ & $76 \pm 4$ \\
$R_{\mathrm{Cu}}{ }^{2+}$ & $\%$ & $96 \pm 4$ & $95 \pm 5$ & $94 \pm 6$ \\
$R_{\mathrm{Fe}}{ }^{2+}$ & $\%$ & $96 \pm 4$ & $95 \pm 5$ & $93 \pm 7$ \\
$J_{\mathrm{H}_{2} \mathrm{SO}_{4}}$ & $\mathrm{~g} \cdot \mathrm{m}^{-2} \cdot \mathrm{h}^{-1}$ & $66 \pm 3$ & $71 \pm 3$ & $72 \pm 3$ \\
$w_{\mathrm{H}_{2} \mathrm{SO}_{4}, F E E D}$ & $\%$ & $4.8 \pm 0.1$ & $4.9 \pm 0.1$ & $4.9 \pm 0.1$ \\
$w_{\mathrm{H}_{2} \mathrm{SO}_{4}, D I F}$ & $\%$ & $4.4 \pm 0.1$ & $4.4 \pm 0.1$ & $4.6 \pm 0.1$ \\
$w_{\mathrm{H}_{2} \mathrm{SO}_{4}, D I A}$ & $\%$ & $1.30 \pm 0.02$ & $1.19 \pm 0.02$ & $1.25 \pm 0.03$ \\
$P_{\mathrm{FEED}}$ & $\%$ & $75.7 \pm 1.6$ & $76.0 \pm 1.3$ & $75.8 \pm 1.3$ \\
$P_{\mathrm{DIFF}}$ & $\%$ & $98.2 \pm 0.1$ & $97.6 \pm 0.2$ & $97.2 \pm 0.2$ \\
$P_{\mathrm{DIF}} / P_{\mathrm{DIA}}$ & - & 2.2 & 2.3 & 2.2 \\
\hline
\end{tabular}

Table 5. Inlet and outlet stream flows (volumetric flows in $\mathrm{L} \cdot \mathrm{h}^{-1}$ and mass flows in $\mathrm{kg} \cdot \mathrm{h}^{-1}$ )

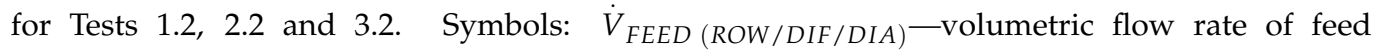

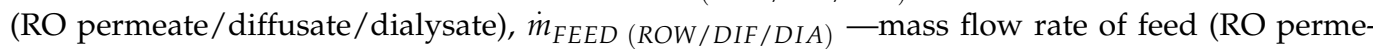
ate/diffusate/dialysate).

\begin{tabular}{cccc}
\hline Parameter & Test 1.2 & Test 2.2 & Test 3.2 \\
\hline$\dot{V}_{\text {FEED }}$ & $9.04 \pm 0.05$ & $9.18 \pm 0.05$ & $9.36 \pm 0.05$ \\
$\dot{V}_{R O W}$ & $6.93 \pm 0.05$ & $7.23 \pm 0.05$ & $6.95 \pm 0.05$ \\
$\dot{V}_{D I F}$ & $7.36 \pm 0.07$ & $7.59 \pm 0.08$ & $7.51 \pm 0.08$ \\
$\dot{V}_{D I A}$ & $8.59 \pm 0.09$ & $8.82 \pm 0.09$ & $8.81 \pm 0.09$ \\
$\dot{m}_{F E E D}$ & $9.32 \pm 0.05$ & $9.46 \pm 0.05$ & $9.65 \pm 0.05$ \\
$\dot{m}_{R O W}$ & $6.91 \pm 0.05$ & $7.22 \pm 0.05$ & $6.94 \pm 0.05$ \\
$\dot{m}_{D I F}$ & $7.57 \pm 0.15$ & $7.80 \pm 0.16$ & $7.72 \pm 0.15$ \\
$\dot{m}_{D I A}$ & $8.66 \pm 0.17$ & $8.88 \pm 0.18$ & $8.87 \pm 0.18$ \\
\hline
\end{tabular}

If the $R_{V}$ parameter is higher than 1 , then acid yield decreases. On the other hand, the weight fraction of acid in the diffusate increases and approaches the concentration of acid in the feed stream (Table 6). With a higher feed flow rate, the residence time of the dialysate in the module is shorter for acid transfer, so a smaller portion of the fed acid will be recovered. Since stripping medium flows at lower velocity, it will leave the module enriched with an acid (and metal ions as well) with a higher components' concentration.

Table 6. Analytical measurements for Test 3.2.

\begin{tabular}{ccccc}
\hline Composition & Unit & Feed & Diffusate & Dialysate \\
\hline $\mathrm{H}_{2} \mathrm{SO}_{4}$ & $\mathrm{~g} \cdot \mathrm{L}^{-1}$ & $50.4 \pm 1.0$ & $47.5 \pm 0.9$ & $12.6 \pm 0.3$ \\
$\mathrm{Fe}^{2+}$ & $\mathrm{ppm}$ & $286 \pm 14$ & $25 \pm 1$ & $282 \pm 14$ \\
$\mathrm{Cu}^{2+}$ & $\mathrm{ppm}$ & $45 \pm 2$ & $3.7 \pm 0.2$ & $45 \pm 2$ \\
Density & $\mathrm{kg} \cdot \mathrm{L}^{-1}$ & $1.031 \pm 0.001$ & $1.028 \pm 0.001$ & $1.008 \pm 0.001$ \\
\hline
\end{tabular}

\subsection{Membrane Properties}

According to the manufacturer, the module includes a commercial anion exchange membrane Fumasep ${ }^{\circledR}$ FAD-PET-75 (Fumatech BWT GmbH, Bietigheim-Bissingen, Germany). Fumasep ${ }^{\circledR}$ FAD-PET-75 is a PET-reinforced anion exchange membrane with low resistance, high acid transfer rate, high mechanical stability, and high stability in an acidic environment. After exposition of the membrane to the acidic environment no significant differences in the IR spectra are observed (Figure $3 b$ ). Figure $3 b$ shows typical stress-strain 
curves of membranes before and after use. The curves show the elastic region, yield and strain hardening.

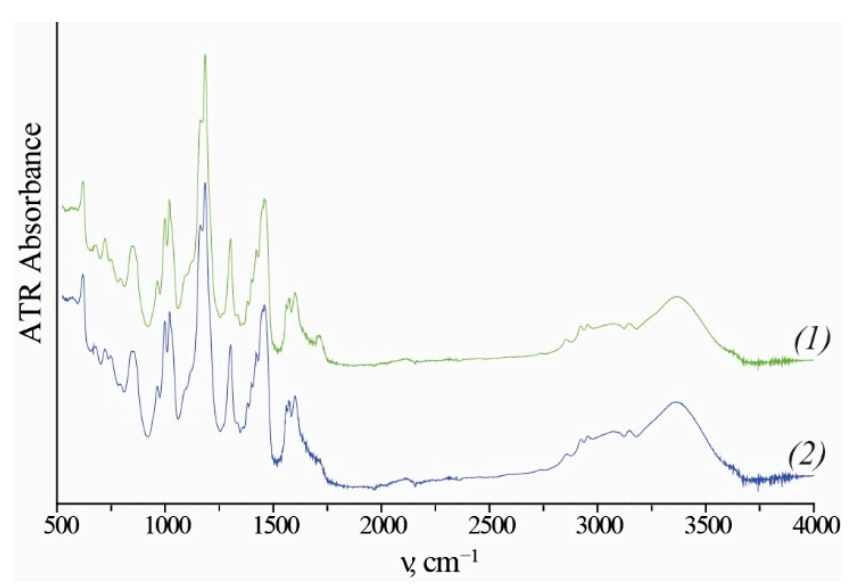

(a)

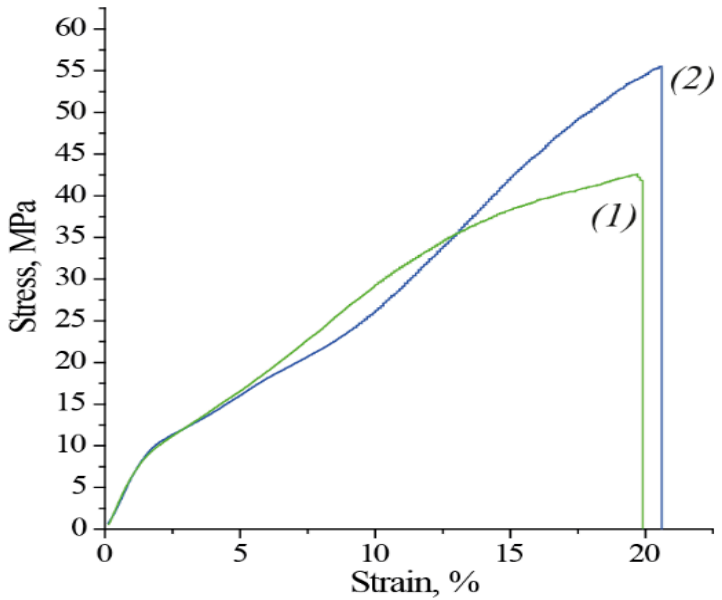

(b)

Figure 3. (a) Fourier transform infrared spectroscopy (FT-IR) spectra and (b) stress-strain curves for membranes (1) before use (initial state) and (2) after use (in a dry state, $\mathrm{Cl}^{-}$form).

After the operation Young's modulus, Yield strength and Elongation at break do not change, and the Tensile strength even increases (Table 7). Visually, there are no cracks or traces of degradation of the polyethylene terephthalate (PET) mesh on both SEM images (Figure 4). Most of the physicochemical properties of membranes do not change significantly, but diffusion permeability increases by $22 \%$ and permselectivity decrease by $1.4 \%$ (Table 7).

Table 7. Physical and chemical parameters of Fumasep ${ }^{\circledR}$ FAD-75.

\begin{tabular}{|c|c|c|c|}
\hline Parameter & Unit & Value (Initial) & Value (after Use) \\
\hline Thickness (dry) & $\mu$ & $76 \pm 1$ & $78 \pm 1$ \\
\hline Ion exchange capacity $\left(\mathrm{Cl}^{-}\right.$form $)$ & $\mathrm{meq} \cdot \mathrm{g}^{-1}$ & $1.51 \pm 0.03$ & $1.53 \pm 0.03$ \\
\hline Specific conductivity in $\mathrm{SO}_{4}^{-}$form & $\mathrm{mS} \cdot \mathrm{cm}^{-1}$ & $22 \pm 2$ & $15 \pm 1$ \\
\hline Permselectivity (at $0.1 / 0.5 \mathrm{~mol} \cdot \mathrm{kg}^{-1} \mathrm{NaCl}$ ) & $\%$ & $92.2 \pm 0.4$ & $90.8 \pm 0.4$ \\
\hline Water uptake & wt. $\%$ & $28 \pm 1$ & $26 \pm 1$ \\
\hline Young's modulus & $\mathrm{MPa}$ & $750 \pm 30$ & $740 \pm 30$ \\
\hline Yield strength & $\mathrm{MPa}$ & $8.5 \pm 0.5$ & $9.4 \pm 0.5$ \\
\hline Tensile strength & $\mathrm{MPa}$ & $42 \pm 1$ & $55 \pm 1$ \\
\hline Elongation at break & $\%$ & $19 \pm 2$ & $22 \pm 2$ \\
\hline $\mathrm{CuSO}_{4}$ diffusion permeability coefficient at $0.1 \mathrm{M} \mathrm{CuSO}_{4}$ & $\mathrm{~cm}^{2} \cdot \mathrm{s}^{-1}$ & $(3.0 \pm 0.2) \cdot 10^{-7}$ & $(3.7 \pm 0.2) \cdot 10^{-7}$ \\
\hline $\mathrm{H}_{2} \mathrm{SO}_{4}$ diffusion permeability coefficient at $0.1 \mathrm{M} \mathrm{H}_{2} \mathrm{SO}_{4}$ & $\mathrm{~cm}^{2} \cdot \mathrm{s}^{-1}$ & $(3.8 \pm 0.2) \cdot 10^{-6}$ & $(4.6 \pm 0.2) \cdot 10^{-6}$ \\
\hline
\end{tabular}

\subsection{Economic Study}

The following study deals with expenses and savings before and after implementation of the spiral-wound diffusion dialyzers into a generic plant consuming $15 \% \mathrm{H}_{2} \mathrm{SO}_{4}$ and generating acidic waste. The study considers two cases of processing $90 \mathrm{~kg} \cdot \mathrm{h}^{-1}$ acidic wastewater at various degrees of dilution $(5 \%$ and $10 \%)$ by dialysis. Re-concentration to $15 \% \mathrm{H}_{2} \mathrm{SO}_{4}$ is also considered. The treatment section consists of neutralization by $20 \%$ suspension of slaked lime (technical-grade purity, $90 \%$ ) according to a scheme shown in Figure 5A,B. 

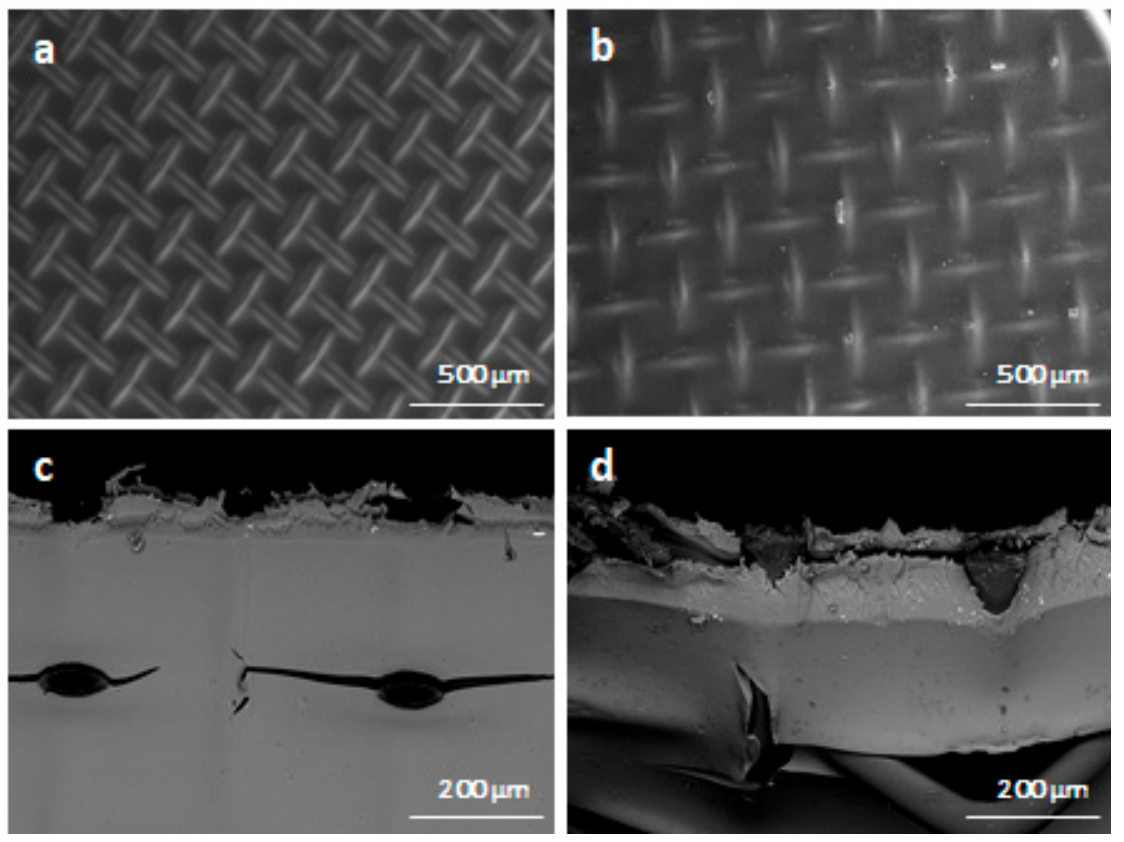

Figure 4. Scanning electron microscopy images detailing membrane state before use ((a) surface, (c) cross-section)) and after use ((b) surface, (d) cross-section).

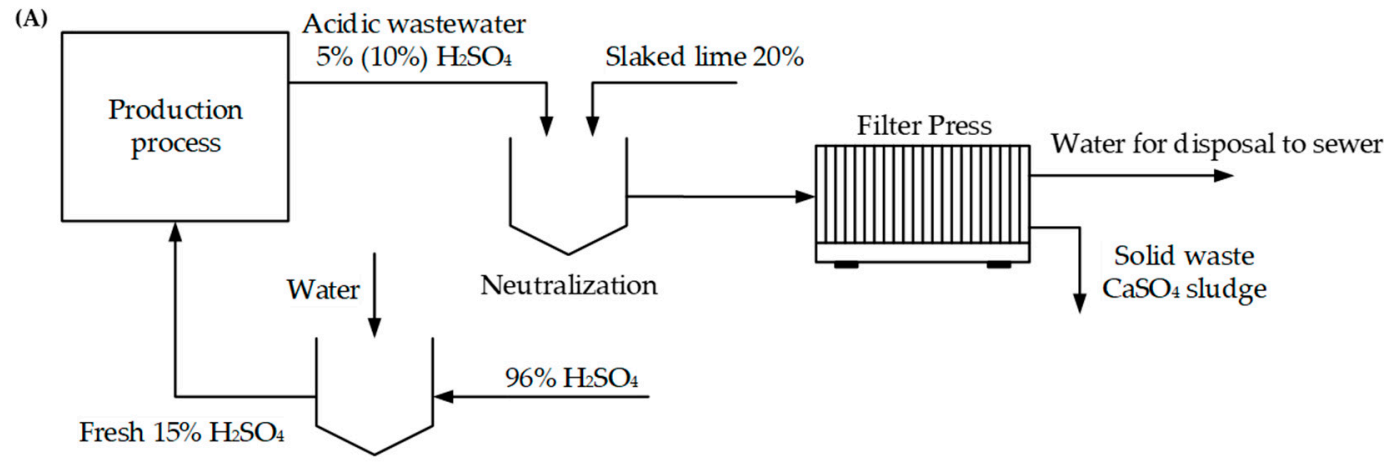

Fresh acid production

(B)

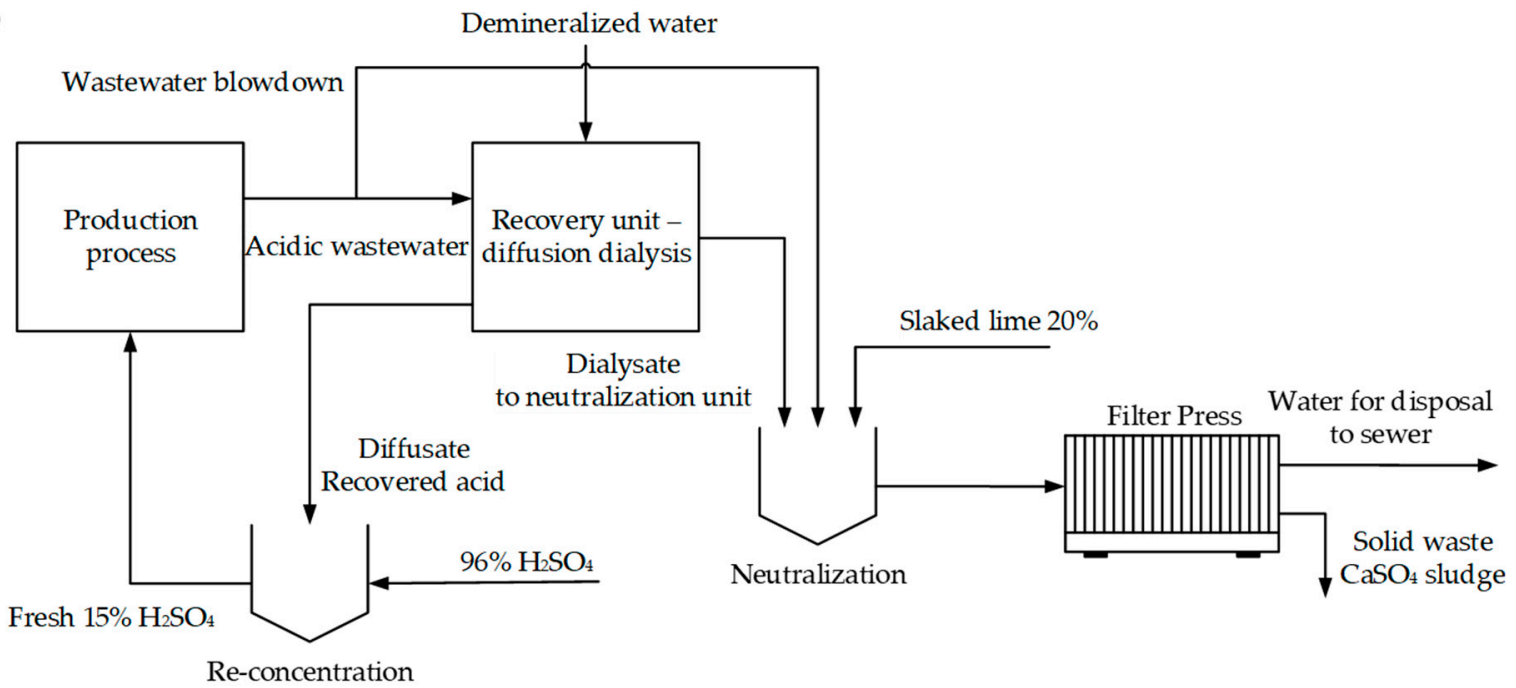

Figure 5. Process flow diagram for the proposed treatment technology. (A) treatment of acidic wastewater without diffusion dialysis; (B) implementation of dialysis into production-level wastewater management. 
Solid-liquid suspension after neutralization is then processed in a filter press. The moisture of the solid phase was considered $65 \%$. Economic rentability is based on the usage of 10 modules processing $90 \mathrm{~kg} / \mathrm{h}$ of acidic feed and on the consumption of $90 \mathrm{~kg} / \mathrm{h}$ of demineralized water. The yield of acid was considered $88 \%$ in the whole range of studied concentrations of $\mathrm{H}_{2} \mathrm{SO}_{4}$ in waste from $5 \%$ to $10 \%$. No other salts than $\mathrm{CaSO}_{4}$ were considered (treated wastewater did not contain any dissolved salt for the sake of simplicity). In real applications, the metal ions $\left(\mathrm{Fe}^{2+}, \mathrm{Zn}^{2+}, \mathrm{Ni}^{2+}, \mathrm{Cu}^{2+}\right.$, etc.) are precipitated in the hydroxide form out of the solution together with gypsum. Therefore, the mass of solid waste increases proportionally to the concentration of metal ions. To evaluate operating expenses, consumption of electricity of the pumps for the dialyzers, demineralized water for sulphuric acid stripping, $96 \%$ sulphuric acid for make-up, slaked lime and disposal of solid waste were taken into consideration. Unit prices of the abovementioned inputs can be found in Table 8 . The values can vary from case to case and are only rough numbers. The total power consumption of the pumps of the unit is considered $1 \mathrm{~kW}$. The capital cost of the unit containing 10 modules is around 52,400 USD. In practical applications pre-filtration unit to prevent insoluble particles from penetration into modules is required and its costs need to be considered. The time allowance for the calculation is 330 working days per year and $24 \mathrm{~h}$ per day.

Table 8. Unit costs of the considered sources. The price of electricity reflects the situation in the Czech Republic.

\begin{tabular}{ccc}
\hline Item & Unit & Unit cost \\
\hline Electricity & $\mathrm{USD} / \mathrm{kWh}$ & 0.1 \\
Demineralized water & $\mathrm{USD} / \mathrm{m}^{3}$ & 10 \\
$96 \% \mathrm{H}_{2} \mathrm{SO}_{4}$ & $\mathrm{USD} / \mathrm{t}$ & 400 \\
$90 \% \mathrm{Ca}(\mathrm{OH})_{2}$ & $\mathrm{USD} / \mathrm{t}$ & 120 \\
Solid waste disposal & $\mathrm{USD} / \mathrm{t}$ & 300 \\
\hline
\end{tabular}

Regardless of the studied case, implementation of the recovery unit will lead to significant savings of neutralization agent, concentrated sulphuric acid and money for sludge disposal. Savings of sources, both material (sulphuric acid) and financial, are visible in a summary of operational expenditures (Table 9). Despite $88 \%$ of acid recovery, saving of neutralization agent needed to treat not only dialysate but also blowdown stream is $74 \%$.

Table 9. Annual expenses for each case of the economic study. (A1) processing $5 \% \mathrm{H}_{2} \mathrm{SO}_{4}$ wastewater without DD; (B1) processing $5 \% \mathrm{H}_{2} \mathrm{SO}_{4}$ wastewater with DD; (A2) processing $10 \% \mathrm{H}_{2} \mathrm{SO}_{4}$ wastewater without DD; (B2) processing $10 \% \mathrm{H}_{2} \mathrm{SO}_{4}$ wastewater with DD.

\begin{tabular}{cccccc}
\hline Case & Unit & A1 & B1 & A2 & B2 \\
\hline Slaked lime 90\% & USD & 4230 & 1083 & 8444 & 2151 \\
Sludge disposal & USD & 50,153 & 12,846 & 100,121 & 25,508 \\
Electricity & USD & $\mathrm{n} / \mathrm{a}$ & 792 & $\mathrm{n} / \mathrm{a}$ & 792 \\
Sulphuric acid 96\% & USD & 52,703 & 39,635 & 52,606 & 26,470 \\
Water & USD & 8530 & 7490 & 9927 & 7848 \\
Total & USD & 115,616 & 61,846 & 171,098 & 62,769 \\
\hline
\end{tabular}

From the graphs, it is evident that a significant part of costs is represented by sludge disposal (Figure 6). It is therefore important to pay attention to the maximal possible removal of moisture. Economic calculations have shown that simple payback time can be less than one year and is a strong function of the acid concentration in the treated feed entering the recovery unit. The more dilute acid is processed, the longer is the payback period (Table 10). 

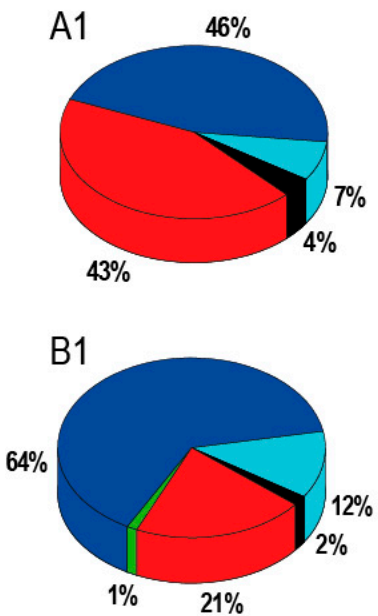
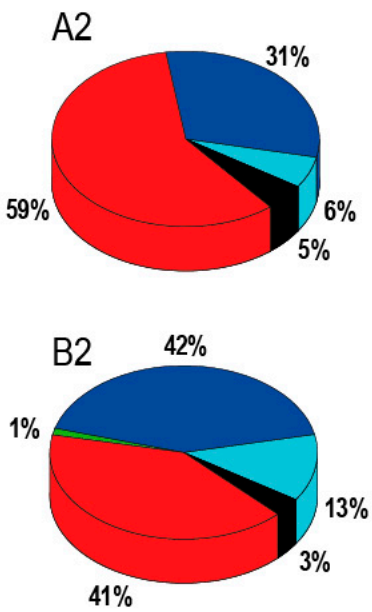

Slaked lime Sludge disposal

Electricity Sulphuric acid make-up Water

Figure 6. Percentage distribution of operating expenses: (A1) processing $5 \% \mathrm{H}_{2} \mathrm{SO}_{4}$ wastewater without DD; (B1) processing $5 \% \mathrm{H}_{2} \mathrm{SO}_{4}$ wastewater with DD; (A2) processing $10 \% \mathrm{H}_{2} \mathrm{SO}_{4}$ wastewater without DD; (B2) processing $10 \% \mathrm{H}_{2} \mathrm{SO}_{4}$ wastewater with DD.

Table 10. Annual cash flow for each case and expected payback period for DD investment.

\begin{tabular}{cccccc}
\hline Item & Unit & A1 & B1 & A2 & B2 \\
\hline Expenses & USD & 115,616 & 61,846 & 171,098 & 62,769 \\
Savings & USD & 0 & 53,770 & 0 & 108,329 \\
Payback period & year & - & 0.97 & - & 0.48 \\
\hline
\end{tabular}

\section{Discussion}

The higher the flow rate of the stripping medium, the higher acid yield will be achieved, and the more diluted diffusate will be obtained (cf. Table 1). This inherently leads to a higher consumption of deionized water. Electrical conductivity is a function of concentration and composition. In the case of pure, diluted sulphuric acid solution, electrical conductivity is linearly dependent on an acid concentration. Moreover, protons exhibit high mobility, therefore, acidic solutions have high electrical conductivity. Based on this physicochemical knowledge we can assume how much is the diffusate rich in acid.

The yield of sulphuric acid can be approximately $90 \%$, which also means saving roughly $90 \%$ of sources in the neutralization step. Also, by implementing DD the amount of neutralized salt will be decreased by $\sim 90 \%$. The advantage of employing a countercurrent configuration of stream flows can be deduced from the obtained results. The concentration of the recovered acid is close to the initial feed value (cf. Table 1). Therefore, an extensive reconcentration step after DD will not be necessary for many applications. Metal cations are retained mainly in the dialysate due to repulsion of cationic species by AEMs with a small concentration of free acid, less than $1 \mathrm{wt} . \%$.

After evaluation of data obtained from analytical analyses, it was found out that the temperature of the feed has an effect on the module performance (cf. Table 4) up to $30^{\circ} \mathrm{C}$. However, this effect is not as significant as the effect of a volumetric-flow ratio. The yield of the acid increased, which is following increased sulphuric acid mass flux through the membranes. Although, at the expense of lower rejection factors of metal ions. This observation can be explained by the relaxation of the membranes. Higher temperatures could modify the internal structure $[28,29]$ of the AEM in a way that the membranes became more permeable for each solute present in the solution. Also, increasing flows can be attributed to the fact that diffusion is the activation process that is accelerated with increasing temperature. Moreover, at temperatures higher than $30^{\circ} \mathrm{C}$, temperature plays a minor role in a mass transfer.

Concentrations of free acid and salts in the wastewater can vary from case to case. In this experimental study, highly acidic conditions (acidity $~ 1 \mathrm{M}$ ) and somewhat moderate 
conditions in terms of metal ion concentration $\left(<1 \mathrm{~g} \cdot \mathrm{L}^{-1}\right)$ were considered. Obtained results showed that the yield of sulphuric acid was in the case of unit flowrate ratio $88 \%$. However, it was reported [18] that salts can enhance a mass transfer of a free acid what consequently results in its higher yield.

The physicochemical properties change indicates the high chemical and mechanical stability of membranes. The only evidence of degradation is a slight drop in membrane selectivity and an increase in diffusion permeability. This is a good result relative to other types of membranes, for membranes based on bromomethylated poly (phenylene oxide) (BPPO) degradation manifested in a drop of ion-exchange capacity $[25,26]$.

The payback period can be influenced by several phenomena. Expenses of the cleaningin-place procedure were excluded from the study since modules unlike RO modules and at good feed quality (no oil, suspended solids, surfactants, or detergents), do not require cleaning. Costs for replacements of the safety AC filters were also excluded from the calculations because pre-filtering will be dependent on the individual cases. Another parameter that is normally measured before release into surface water is dissolved solids. The limit value varies with location and is not the same for each company. In the case of neutralization of wastewater containing sulphuric acid, low soluble calcium sulphate is generated. Its solubility at $25^{\circ} \mathrm{C}$ is $2.6 \mathrm{~g} \cdot \mathrm{L}^{-1}$. From this point of view, emission of such water usually should not lead to fees due to high total dissolved solids. However, the situation is more complicated with wastewater containing $\mathrm{HCl}$, since neutralization of this acid generates very soluble $\mathrm{CaCl}_{2}$. For this reason, recovery of $\mathrm{HCl}$ should have its place in wastewater management instead of simple neutralization. However, the rejection factor for some metal ions like $\mathrm{Zn}^{2+}$ in dialysis of $\mathrm{HCl}$ wastewater is lower due to the formation of negatively charged chloro complexes [18], which are not repulsed by the fixed groups and therefore diffuse through the AEM easily. Nevertheless, each case should be assessed separately with a thorough economical study. Actual unit costs should be used to clarify outcomes and benefits after the DD implementation.

\section{Material and Methods}

\subsection{Feed Solution}

A $25 \mathrm{~L}$ model solution consisting of sulphuric acid with impurities of iron and copper sulphate was used for each experiment, with a fresh model solution being prepared for each continuous test. The model solution comprised $0.732 \mathrm{~L}$ of $96 \%$ sulphuric acid (Penta s.r.o., p.a.), $37.3 \mathrm{~g}$ of iron(II) sulphate heptahydrate (Penta s.r.o., pure), $4.9 \mathrm{~g}$ of copper (II) sulphate pentahydrate (Penta s.r.o., p.a.) and reverse osmosis (RO) permeate $\left(\mathrm{k}<10 \mu \mathrm{S} \cdot \mathrm{cm}^{-1}\right)$. When made up to $25 \mathrm{~L}$ with demineralized water, the resulting solution comprised ca. $5 \mathrm{wt}$. \% of sulphuric acid, $300 \mathrm{ppm}$ of $\mathrm{Fe}^{2+}$ and $50 \mathrm{ppm}$ of $\mathrm{Cu}^{2+}$ (Table 11). The electrical conductivity of the feed solution ranged from 215 to $231 \mathrm{mS} \cdot \mathrm{cm}^{-1}$ at $25^{\circ} \mathrm{C}$.

Table 11. Average composition of feed solution.

\begin{tabular}{ccc}
\hline Composition & Unit & Feed Stream \\
\hline $\mathrm{H}_{2} \mathrm{SO}_{4}$ & $\mathrm{~g} \cdot \mathrm{L}^{-1}$ & $51 \pm 1$ \\
$\mathrm{Fe}^{2+}$ & $\mathrm{ppm}$ & $283 \pm 14$ \\
$\mathrm{Cu}^{2+}$ & $\mathrm{ppm}$ & $45 \pm 2$ \\
Electrical conductivity & $\mathrm{mS} \cdot \mathrm{cm}^{-1}$ & $221.5 \pm 1.1$ \\
Density & $\mathrm{kg} \cdot \mathrm{L}^{-1}$ & $1.031 \pm 0.001$ \\
\hline
\end{tabular}

\subsection{Analytical Methods}

Determination of composition was undertaken via potentiometric alkalimetry for measuring free acid content and inductively coupled plasma (ICP-OES) coupled with optical emission spectroscopy (both Thermo Fischer Scientific GmbH, Bremen, Germany) for measuring metallic ion concentration by a method of a calibration curve. Standard samples had concentrations of $0.1 ; 0.5 ; 1 ; 5 ; 10$ and $100 \mathrm{ppm}$. 
The main parameters which were measured during acid-recovery experiments were electrical conductivity, temperature, density, volumetric flow, and mass flow. Electrical conductivity and temperature were determined using a TetraCon 925/LV-P probe (Xylem Analytics WTW, Germany) connected to a WTW 3430 Multimeter (Xylem Analytics WTW, Germany). Density was measured with a portable hand-held Densito 30PX density meter (Mettler Toledo, Japan). A KERN 572 balance (KERN \& SOHN GmbH, Balingen), cylinder and a timer were used for determination of mass flow.

\subsection{Equipment}

A WD-AR10-2001 spiral-wound module (Spiraltec GmbH, Germany) with an effective anion exchange area of ca. $5 \mathrm{~m}^{2}$ was used to test the effects of flow rate ratio and temperature on recovery of spent sulphuric acid by DD (Table 12).

Table 12. Spiral-wound module characteristics. Parameters were downloaded from the online module datasheet [30].

\begin{tabular}{cc}
\hline Parameter & Value \\
\hline Flow & $5-15 \mathrm{~L} \cdot \mathrm{h}^{-1}$ each channel \\
Pressure loss & $80 \mathrm{mbar}\left(\right.$ at $\left.5 \mathrm{~L} \cdot \mathrm{h}^{-1}\right)-400 \mathrm{mbar}\left(\right.$ at $\left.15 \mathrm{~L} \cdot \mathrm{h}^{-1}\right)$ \\
Operating pressure & $0.1-1.5 \mathrm{bar}(\mathrm{g})$ \\
Differential pressure & $<200 \mathrm{mbar}($ between the channels $)$ \\
Operating temperature & $5{ }^{\circ} \mathrm{C}-40^{\circ} \mathrm{C}$ \\
Empty weight & $\mathrm{ca} .8 \mathrm{~kg}$ \\
Fill volumes & ca. $4.5 \mathrm{~L}$ each channel \\
\hline
\end{tabular}

\subsection{Membrane Characterization}

$\mathrm{CuSO}_{4}$ diffusion permeability was determined from the $\mathrm{CuSO}_{4}$ flow with the membrane placed between the 0.1 and $0.001 \mathrm{M} \mathrm{CuSO}_{4}$ solutions. Measurements were conducted at room temperature $\left(24^{\circ} \mathrm{C}\right)$ in a two-section plexiglass cell with a $5 \mathrm{~cm}^{2}$ active membrane area, the solutions being constantly stirred at ca. $400 \mathrm{rpm}$ by a tailor-made twoposition magnetic stirrer. $\mathrm{CuSO}_{4}$ flow was determined using an Expert-002 conductometer (Econix-Expert, Russia). Using a similar method, sulphuric acid diffusion permeability was determined from the $\mathrm{H}_{2} \mathrm{SO}_{4}$ flow with the membrane placed between the $0.1 \mathrm{M} \mathrm{Na}_{2} \mathrm{SO}_{4}$ and $0.1 \mathrm{M} \mathrm{H}_{2} \mathrm{SO}_{4}$ solutions. $\mathrm{H}_{2} \mathrm{SO}_{4}$ flow was calculated from $\mathrm{pH}$ change in salt solution determined using an Expert-pH pH-meter (Econix-Expert, Russia).

AC-membrane ionic resistance was determined via the four-electrode method, using a thermostatic $25{ }^{\circ} \mathrm{C}$ cell filled with a $0.5 \mathrm{M} \mathrm{NaCl}$ solution and a P-40X potentiostatgalvanostat with an FRA-24M impedance measurement module (Elins, Russia). A detailed description of the experiment can be found elsewhere [31].

Permselectivity was characterized by the potentiostat technique, the membrane being placed between $0.1 \mathrm{M}$ and $0.5 \mathrm{M} \mathrm{NaCl}$ solutions in a two-compartment cell. A detailed description of the experiment and calculations can be found elsewhere [32].

Stress-strain experiments were performed using a Tinius Olsen H5KT universal testing machine and a force sensor set at $100 \mathrm{~N}$ under ambient conditions $\left(24{ }^{\circ} \mathrm{C} / 25 \%\right.$ relative humidity). The gauge length of the samples was adjusted to $50 \mathrm{~mm}$ for the machine and the strain rate was set at $5 \mathrm{~mm} / \mathrm{min}$ for all tests. A more detailed description of the experiment can be found elsewhere [33].

Water uptake was determined from weight loss after drying the film at $80^{\circ} \mathrm{C}$ for several hours. Dimensional swelling was determined by the change in geometric dimensions of the membrane sample before and after dehydration.

Scanning electron microscope (SEM) images were obtained using a Quanta FEG 450 SEM (FEI, Hillsboro, OR, USA) at $10 \mathrm{kV}$ accelerating voltage and $80 \mathrm{~Pa}$ residual pressure. A detailed description of ion exchange capacity measurement and calculation can be found elsewhere [32]. The thickness of each sample was taken as the average value of five points measured before the experiment using a Mitutoyo 293-805 micrometer (Mitutoyo, Japan). 
FTIR spectra of the samples were measured using a Nicolet iS5 spectrometer (Thermo Fisher Scientific, USA) in attenuated total reflection mode using a Quest Specac accessory (400-4000 $\mathrm{cm}^{-1}$ spectral range, 32 scans, $2 \mathrm{~cm}^{-1}$ resolution).

\subsection{Experimental Setup of Diffusion Dialysis Tests}

Two series of tests were conducted in a continuous regime to study process parameter impacts on system performance in terms of free-acid yield, metal-ion rejection, and output stream composition. The first series consisted of tests performed at different ratios $\left(R_{\mathrm{V}}\right)$ of acidic feed:demineralized water-inlet-volumetric flow in $\mathrm{L}^{-1}{ }^{-1}$ at laboratory temperature $\left(20-25^{\circ} \mathrm{C}\right)$. The second series consisted of tests performed at different feed temperatures ( $T_{\mathrm{F}}$; from $20^{\circ} \mathrm{C}$ to $40^{\circ} \mathrm{C}$ ) at fixed $R_{\mathrm{V}}$ (conditions summarized in Table 13 ).

Table 13. Conditions for Series 1 and Series 2 tests. Symbols: $R_{\mathrm{V}}$-volumetric flow rate ratio (feed/RO permeate), $T_{\mathrm{F}}$-temperature of the inlet feed.

\begin{tabular}{ccccccc}
\hline Parameter & Unit & Test 1.1 & Test 2.1 & Test 1.2 & Test 2.2 & Test 3.2 \\
\hline$R_{\mathrm{V}}$ & - & $9 / 9$ & $9 / 11$ & $9 / 7$ & $9 / 7$ & $9 / 7$ \\
$T_{\mathrm{F}}$ & ${ }^{\circ} \mathrm{C}$ & $20-25$ & $20-25$ & $20-25$ & 30 & 40 \\
\hline
\end{tabular}

Samples were collected from the outlet streams once the process had reached a steadystate. To check the state of the process, diffusate and the dialysate conductivity and flowrate were measured over time, with flowrate measured using the cylinder method (i.e., time needed to fill a cylinder with $100 \mathrm{~mL}$ of liquid).

The experimental process consists of two parts, a hydraulic feed and diffusate and dialysate outlet streams (Figure 7). The hydraulic part consists of two Flojet pumps (Xylem Inc., USA), two filters (a $5 \mu \mathrm{m}$ filter for the RO permeate and an activated carbon (AC) filter for the acidic feed stream) and a series of rotameters, pressure indicators and MARIC flow control valves (Maric Flow Control, Australia). Manual needle valves were located in the recirculation pipes to allow fine regulation of pressure and volumetric flow. High temperature levels $\left(30^{\circ} \mathrm{C}\right.$ and $\left.40^{\circ} \mathrm{C}\right)$ were maintained in the feed solution by indirectly heating the salty acid barrel with a heating belt.

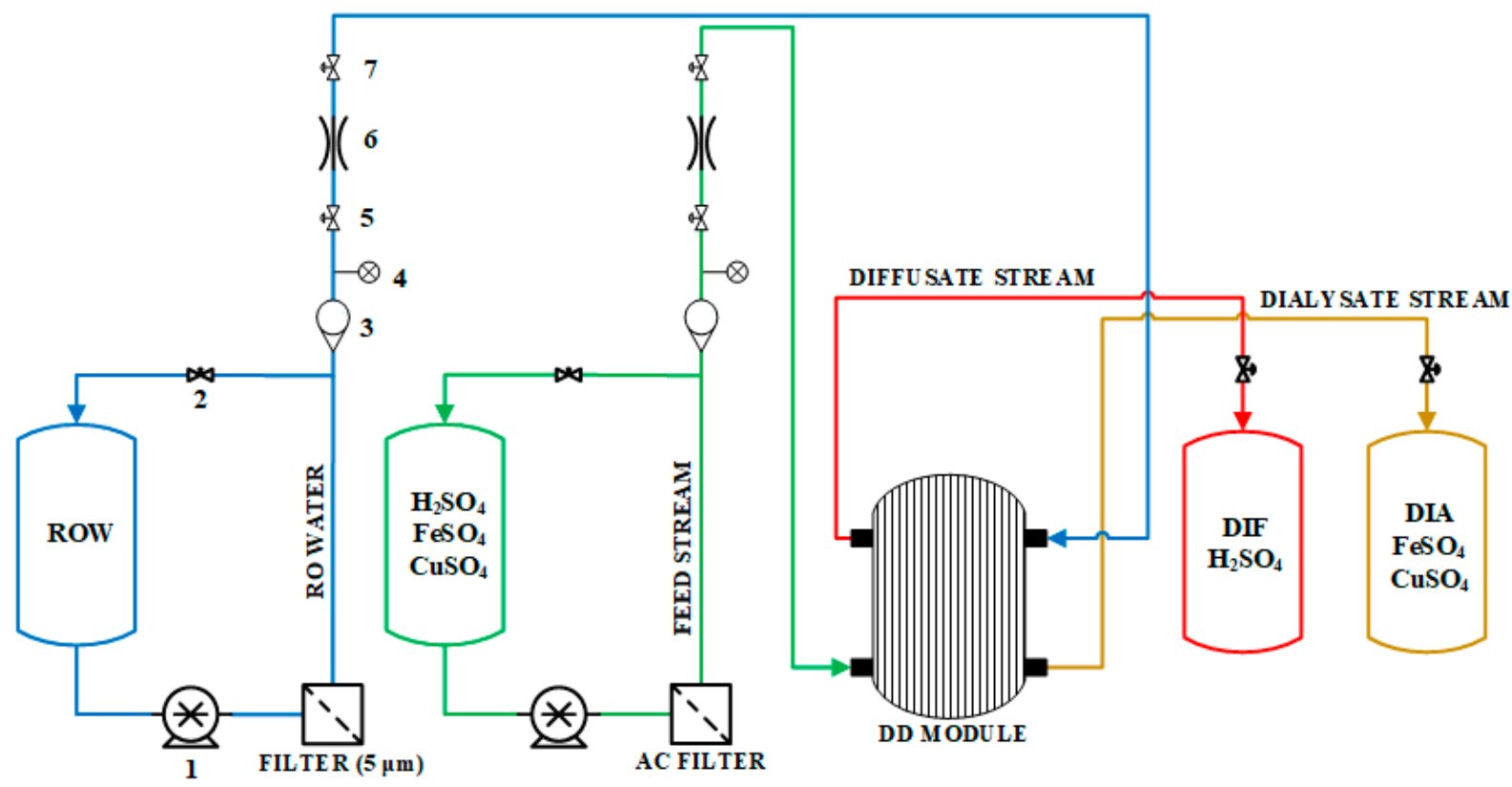

Figure 7. Simplified process flow diagram of the acid-recovery system. Instrumentation key: (1) pump; (2) needle valve; (3) rotameter; (4) pressure sensor; (5) manual valve; (6) flow control valve; (7) manual valve. 
The diffusate and dialysate were collected in separate tanks. Samples from the outlet streams were collected directly from the sampling cock valves (i.e., not from the tanks) at pre-determined time intervals.

\subsection{Calculations}

Water uptake $(W)$ was calculated by the following Equation (1):

$$
W=\frac{m_{w e t}-m_{d r y}}{m_{d r y}} \times 100 \%
$$

where, $m_{\text {wet }}$ and $m_{\text {dry }}$ represent the membrane weight before and after dehydration.

The diffusion permeability coefficients $\left(P_{S}\right)$ was calculated using the following Equation (2):

$$
P_{s}=\frac{J_{s} d_{m}}{\Delta C_{s}}
$$

where, $J_{s}$ is solute flow, $d_{m}$ is membrane thickness and $\Delta C_{s}$ is the solute concentration difference.

The area resistance $\left(R_{\text {area }}\right)$ and specific conductivity $(\sigma)$ were calculated using the following Equations (3) and (4):

$$
\begin{gathered}
R_{\text {area }}=\left(R_{\text {cell }+ \text { mem }}-R_{\text {cell }}\right) \times S \\
\sigma=\frac{d_{m}}{R_{\text {area }}}
\end{gathered}
$$

where, $R_{\text {cell }+ \text { mem }}$ and $R_{\text {cell }}$ represent cell resistance with and without the membrane and $S$ is the membrane active area.

According to [34], Young's modulus is calculated from the slope of the initial section of the stress-strain curve. The yield strength (transition from elasticity to plasticity) corresponded to the first local maximum of the 1-st order derivative of the stress-strain curve. In this case, tensile strength corresponds to maximum stress.

Volumetric ratio $\left(R_{V}\right)$ was defined according to the following Equation (5):

$$
R_{V}=\frac{\dot{V}_{F E E D}\left(L \cdot h^{-1}\right)}{\dot{V}_{R O W}\left(L \cdot h^{-1}\right)}
$$

where, $\dot{V}_{F E E D}$ represents volumetric flow of the acid fed into the module and $\dot{V}_{R O W}$ represents volumetric flow of demineralized water.

Data evaluation was based on mass balance under steady-state conditions, as described in the following Equation (6):

$$
\sum \dot{m}_{\text {input }}-\sum \dot{m}_{\text {output }}=0
$$

where, $\dot{m}_{\text {input }}\left(\dot{m}_{\text {output }}\right)$ represents the mass flow of streams entering or leaving the system.

For the purpose of this study, Equation (6) has the form:

$$
\dot{m}_{F E E D}+\dot{m}_{R O W}=\dot{m}_{D I A}+\dot{m}_{D I F}
$$

Free-acid yield $(Y)$ can then be calculated from either of the two following Equations (8) and (9):

$$
\begin{gathered}
Y=\frac{\dot{m}_{H^{+}, D I F}}{\dot{m}_{H^{+}, \text {FEED }}} \times 100 \% \\
Y=\left(1-\frac{\dot{m}_{H^{+}, D I A}}{\dot{m}_{H^{+}, F E E D}}\right) \times 100 \%
\end{gathered}
$$


In a steady-state, both Equations (8) and (9) are equivalent and can be derived from the mass balance of free acid in a steady state. The reported values represent average values of free-acid yield obtained from Equations (8) and (9).

Metal-ion rejection $\left(R_{\mathrm{i}}\right)$ can also be calculated from the following two equivalent Equations (10) and (11):

$$
\begin{gathered}
R_{i}=\frac{\dot{m}_{i, D I A}}{\dot{m}_{i, F E E D}} \times 100 \% \\
R_{i}=\left(1-\frac{\dot{m}_{i, D I F}}{\dot{m}_{i, F E E D}}\right) \times 100 \%
\end{gathered}
$$

where, $i=\mathrm{Cu}$ or Fe.

Reported values of metal-ion rejection for each test were calculated as average values from Equations (10) and (11).

Stream composition was used to evaluate stream ionic purity. The ionic purity $\left(P_{j}\right)$ of stream $\mathrm{j}$ was defined as follows (12):

$$
P_{j}=\frac{c_{H^{+}, j}}{c_{H^{+}, j}+\sum_{i} c_{i, j}} \times 100 \%
$$

where, $j$ is FEED, DIF and DIA and $i$ is Fe or $\mathrm{Cu} . c_{i, j}$ is the concentration of the $i$-th compound in the $j$-th stream in ppm.

The total flux of acid $\mathrm{J}_{\mathrm{H}_{2} \mathrm{SO}_{4}}$ was defined as the mass flow of acid $\dot{m}_{\mathrm{H}_{2} \mathrm{SO}_{4}}$ per effective membrane area $(S)$ :

$$
\mathrm{J}_{\mathrm{H}_{2} \mathrm{SO}_{4}}=\frac{\dot{m}_{\mathrm{H}_{2} \mathrm{SO}_{4}}}{\mathrm{~S}}
$$

Equations (8)-(13) are especially useful for evaluating the module's separation performance, for comparing the degree of purification of recovered acid with inlet acidic feed or for scaling-up the industrial technology if a required flow of recoverable acid is provided.

\subsection{Statistical Analysis}

Measurement uncertainties for electrical conductivity and temperature were obtained from the manufacturer's own documentation, while measurement uncertainties for heavy metal ion concentration and acidity were obtained by applying the Student's t-distribution with a significance level of $p<0.05$. Mass flow was characterized by a measurement uncertainty of $2 \%$, obtained from the propagation-of-error formula.

\section{Conclusions}

A membrane-based separation process driven by a chemical-potential gradient was successfully used for the treatment of acidic wastewater and recovery of sulphuric acid, with different combinations of acidic feed and demineralized water volumetric-flow ratios influencing system performance in terms of sulphuric acid yield, metal ion rejection and component concentration in recovered-acid and reject streams. The temperature of the acidic feed stream increased mass transfer of both sulphuric acid and dissolved sulphate salts, with a significant effect observed at temperatures up to $30^{\circ} \mathrm{C}$.

A techno-economic study indicated that inclusion of DD into recovery of sulphuric acid from wastewater was viable and feasible, even for dilute solutions (5 wt.\% sulphuric acid), with a simple payback period of ca 1 year. The payback period would be even shorter where more concentrated spent streams were generated.

A comparison of basic membrane (Fumasep ${ }^{\circledR}$ FAD-PET-75) physicochemical properties (i.e., ion exchange capacity, water uptake, thickness, permselectivity, acid and salt diffusion permeability, ionic conductivity, and stress-strain curves) before and after dialysis indicated only a slight drop in membrane selectivity and an increase in diffusion permeability. Furthermore, there were no significant changes in membrane IR spectra. Taken together, this indicates a relatively high chemical and mechanical membrane stability. 
Author Contributions: Conceptualisation, L.Č., A.M., L.Š. and L.D.; Formal analysis, D.G., L.Č. and L.Š.; Methodology, A.M., L.D. and L.Š.; Project administration, L.Č., L.Š. and A.M.; Visualization, A.M., L.Č., and D.G.; Writing of original draft, A.M., L.Č., L.D., D.G. and L.Š.; Writing-review and editing, A.M., L.C.., D.G. and L.D. All authors have read and agreed to the published version of the manuscript.

Funding: Work performed by MemBrain s.r.o. (Membrane Innovation Centre) was performed under an Institutional support project (Decision No. 6/2018) of the Ministry of Industry and Trade of the Czech Republic.

Institutional Review Board Statement: Not applicable.

Informed Consent Statement: Not applicable.

Data Availability Statement: The data presented in this study are available on request from the corresponding author.

Conflicts of Interest: The authors declare no conflict of interest.

$\begin{array}{ll}\text { Abbreviations } \\ \text { AC } & \text { Activated carbon } \\ \text { AEMs } & \text { Anion-exchange membranes } \\ \text { BPPO } & \text { Bromomethylated poly (phenylene oxide) } \\ \text { DD } & \text { Diffusion dialysis } \\ \text { DIA } & \text { Dialysate } \\ \text { DIF } & \text { Diffusate } \\ \text { FEED } & \text { Salty acid fed to a module } \\ \text { PET } & \text { Polyethylene terephthalate } \\ \text { R.H. } & \text { Relative humidity } \\ \text { RO } & \text { Reverse osmosis } \\ \text { ROW } & \text { Permeate of reverse osmosis } \\ \text { SEM } & \text { Scanning electron microscope } \\ \text { USD } & \text { United States dollar }\end{array}$

\section{References}

1. Watzlaf, G.R.; Schroeder, K.T.; Kleinmann, R.L.P.; Kairies, C.L.; Nairn, R.W. The Passive Treatment of Coal Mine Drainage; United States Department of Energy National Energy Technology Laboratory Internal Publication: Pittsburgh, PA, USA, $2004 ;$ pp. 1-72.

2. Hughes, T.A.; Gray, N.F. Removal of metals and acidity from acid mine drainage using municipal wastewater and activated sludge. Mine Water Environ. 2013, 32, 170-184. [CrossRef]

3. López, J.; Gibert, O.; Cortina, J. Integration of membrane technologies to enhance the sustainability in the treatment of metalcontaining acidic liquid wastes. An overview. Sep. Purif. Technol. 2021, 265, 118485. [CrossRef]

4. Merkel, A.; Ashrafi, A.M.; Ondrušek, M. The use of electrodialysis for recovery of sodium hydroxide from the high alkaline solution as a model of mercerization wastewater. J. Water Process. Eng. 2017, 20, 123-129. [CrossRef]

5. Luo, J.; Wu, C.; Xu, T.; Wu, Y. Diffusion dialysis-concept, principle and applications. J. Membr. Sci. 2011, 366, 1-16. [CrossRef]

6. Zhang, C.; Zhang, W.; Wang, Y. Diffusion dialysis for acid recovery from acidic waste solutions: Anion exchange membranes and technology integration. Membranes 2020, 10, 169. [CrossRef] [PubMed]

7. Jiang, S.; Sun, H.; Wang, H.; Ladewig, B.P.; Yao, Z. A comprehensive review on the synthesis and applications of ion exchange membranes. Chemosphere 2021, 282, 130817. [CrossRef]

8. Wang, G.; Xu, J.; Sun, P.; Zhao, X.; Zhang, W.; Lv, L.; Pan, B.; Guo, Q.; Bin, Y.; Wang, J. Principle of diffusion dialysis method and its application in treatment of wastewater of electroplating industry. Ion Exch. Adsorpt. 2015, 31, 569-576. [CrossRef]

9. Kreuer, K.-D. Proton conductivity: Materials and applications. Chem. Mater. 1996, 8, 610-641. [CrossRef]

10. Stenina, I.; Yaroslavtsev, A. Ionic mobility in ion-exchange membranes. Membranes 2021, 11, 198. [CrossRef]

11. Cukierman, S. Et tu, Grotthuss! and other unfinished stories. Biochim. Biophys. Acta (BBA)-Bioenerg. 2006, 1757, 876-885. [CrossRef]

12. Zhang, P.; Wu, Y.; Liu, W.; Cui, P.; Huang, Q.; Ran, J. Construction of two dimensional anion exchange membranes to boost acid recovery performances. J. Membr. Sci. 2021, 618, 118692. [CrossRef]

13. Wu, Y.; Luo, J.; Zhao, L.; Zhang, G.; Wu, C.; Xu, T. QPPO/PVA anion exchange hybrid membranes from double crosslinking agents for acid recovery. J. Membr. Sci. 2013, 428, 95-103. [CrossRef]

14. Sharma, J.; Misra, S.; Kulshrestha, V. Internally cross-linked poly (2,6-dimethyl-1,4-phenylene ether) based anion exchange membrane for recovery of different acids by diffusion dialysis. Chem. Eng. J. 2021, 414, 128776. [CrossRef] 
15. Lin, J.; Huang, J.; Wang, J.; Yu, J.; You, X.; Lin, X.; Van Der Bruggen, B.; Zhao, S. High-performance porous anion exchange membranes for efficient acid recovery from acidic wastewater by diffusion dialysis. J. Membr. Sci. 2021, 624, 119116. [CrossRef]

16. Ye, H.; Zou, L.; Wu, C.; Wu, Y. Tubular membrane used in continuous and semi-continuous diffusion dialysis. Sep. Purif. Technol. 2020, 235, 116147. [CrossRef]

17. Luo, F.; Zhang, X.; Pan, J.; Mondal, A.N.; Feng, H.; Xu, T. Diffusion dialysis of sulfuric acid in spiral wound membrane modules: Effect of module number and connection mode. Sep. Purif. Technol. 2015, 148, 25-31. [CrossRef]

18. Gueccia, R.; Aguirre, A.R.; Randazzo, S.; Cipollina, A.; Micale, G. Diffusion dialysis for separation of hydrochloric acid, iron and zinc ions from highly concentrated pickling solutions. Membranes 2020, 10, 129. [CrossRef]

19. Ruiz-Aguirre, A.; Lopez, J.; Gueccia, R.; Randazzo, S.; Cipollina, A.; Cortina, J.; Micale, G. Diffusion dialysis for the treatment of H2SO4-CuSO4 solutions from electroplating plants: Ions membrane transport characterization and modelling. Sep. Purif. Technol. 2021, 266, 118215. [CrossRef]

20. Gueccia, R.; Winter, D.; Randazzo, S.; Cipollina, A.; Koschikowski, J.; Micale, G.D. An integrated approach for the HCl and metals recovery from waste pickling solutions: Pilot plant and design operations. Chem. Eng. Res. Des. 2021, 168, 383-396. [CrossRef]

21. Saif, H.; Huertas, R.; Pawlowski, S.; Crespo, J.; Velizarov, S. Development of highly selective composite polymeric membranes for $\mathrm{Li}+/ \mathrm{Mg} 2+$ separation. J. Membr. Sci. 2021, 620, 118891. [CrossRef]

22. López, J.; de Oliveira, R.; Reig, M.; Vecino, X.; Gibert, O.; de Juan, A.; Cortina, J. Acid recovery from copper metallurgical process streams polluted with arsenic by diffusion dialysis. J. Environ. Chem. Eng. 2021, 9, 104692. [CrossRef]

23. Zhang, X.; Li, C.; Wang, H.; Xu, T. Recovery of hydrochloric acid from simulated chemosynthesis aluminum foil wastewater by spiral wound diffusion dialysis (SWDD) membrane module. J. Membr. Sci. 2011, 384, 219-225. [CrossRef]

24. Henkensmeier, D.; Najibah, M.; Harms, C.; Žitka, J.; Hnát, J.; Bouzek, K. Overview: State-of-the art commercial membranes for anion exchange membrane water electrolysis. J. Electrochem. Energy Convers. Storage 2020, 18, 1-46. [CrossRef]

25. Khan, M.I.; Luque, R.; Prinsen, P.; Rehman, A.U.; Anjum, S.; Nawaz, M.; Shaheen, A.; Zafar, S.; Mustaqeem, M. BPPO-Based Anion Exchange Membranes for Acid Recovery via Diffusion Dialysis. Materials 2017, 10, 266. [CrossRef]

26. Mao, F.; Zhang, G.; Tong, J.; Xu, T.; Wu, Y. Anion exchange membranes used in diffusion dialysis for acid recovery from erosive and organic solutions. Sep. Purif. Technol. 2014, 122, 376-383. [CrossRef]

27. Lin, X.; Shamsaei, E.; Kong, B.; Liu, J.Z.; Hu, Y.; Xu, T.; Wang, H. Porous diffusion dialysis membranes for rapid acid recovery. J. Membr. Sci. 2016, 502, 76-83. [CrossRef]

28. Merkel, A.; Voropaeva, D.; Fárová, H.; Yaroslavtsev, A. High effective electrodialytic whey desalination at high temperature. Int. Dairy J. 2020, 108, 104737. [CrossRef]

29. Merkel, A.; Fárová, H.; Voropaeva, D.; Yaroslavtsev, A.; Ahrné, L.; Yazdi, S.R. The impact of high effective electrodialytic desalination on acid whey stream at high temperature. Int. Dairy J. 2021, 114, 104921. [CrossRef]

30. Spiraltec GmbH, Sachsenheim, Germany. Available online: https://www.spiraltecgmbh.com/en/downloads-en.html (accessed on 30 October 2021).

31. Golubenko, D.; Pourcelly, G.; Yaroslavtsev, A. Permselectivity and ion-conductivity of grafted cation-exchange membranes based on UV-oxidized polymethylpenten and sulfonated polystyrene. Sep. Purif. Technol. 2018, 207, 329-335. [CrossRef]

32. Golubenko, D.; Van Der Bruggen, B.; Yaroslavtsev, A.B. Novel anion exchange membrane with low ionic resistance based on chloromethylated/quaternized-grafted polystyrene for energy efficient electromembrane processes. J. Appl. Polym. Sci. 2019, 137, 48656. [CrossRef]

33. Safronova, E.; Golubenko, D.; Pourcelly, G.; Yaroslavtsev, A. Mechanical properties and influence of straining on ion conductivity of perfluorosulfonic acid Nafion ${ }^{\circledR}$-type membranes depending on water uptake. J. Membr. Sci. 2015, 473, 218-225. [CrossRef]

34. Deshmukh, K.; Kovářík, T.; Muzaffar, A.; Basheer, A.M.; Pasha, S.K. Chapter 4-Mechanical analysis of polymers. In Polymer Science and Innovative Applications; Elsevier: Amsterdam, The Netherlands, 2020; pp. 117-152. [CrossRef] 